\title{
Direct Taxation of Agricultural Enterprises
}

\author{
Liubov Syniavska, Oksana Grytsyna, Heorhiy Cherevko, Olha Sholudko, Ruslana Sodoma
}

\begin{abstract}
Financial support of the current activity and perspective economic development of the agricultural enterprises in Ukraine still remains a significant problem nowadays. Under the condition of limited budget resources, the necessity of activation of mechanism of government control of economic processes, that is conducted by the methods of legal, administrative and financial economic influence, deserves special attention. Key position in the government economic regulation belongs to the methods of tax adjustment which include the usage of budget, tax, customs, money credit, price making and investment policies means. The study of tax regulation of the agrarian sector of the economy is getting special significance, taking into account the lack of financial resources of agricultural enterprises, tendency to the reduction of the budgetary expenditures on the industry development, intensification of socio-economic problems because of political and economic instability in the country and integration of Ukraine into the world economic community. One of the most acute issues of the current development of the agrarian sector of the economy is the creation of the efficient mechanism of taxation. Today the situation is such that despite the growth of state budget revenues, agrarian business is constantly exposed to tax changes. Though, the practice of law application shows that amendments to the Ukrainian laws concerning taxation very often cause new problems. They relate primarily to the growth of the tax burden on small producers, in particular, farms. Agroholdings minimize their tax payments by acquiring the status of taxpayers of the 4th group. This allows them to accumulate significant funds for investment. Agricultural companies do not legally pay income tax on the land they use. Instead, they pay a meager tax under the simplified system of taxation in agriculture, the amount of which is many times smaller than if they paid under the general system of taxation. The scientific novelty of the obtained results is presented by a set of theoretical and practical aspects of the study, namely proposals for the current state of taxation of agricultural enterprises and recommendations for improving the security of the Ukraine`s taxation.
\end{abstract}

Keywords : agricultural producers, taxation system, direct taxation, tax relations.

Manuscript received on May 25, 2020.

Revised Manuscript received on June 29, 2020.

Manuscript published on July 30, 2020.

* Correspondence Author

Lyubov SYNYAVSKA Associate Professor of the Department of Finance, Banking and Insurance, Lviv National Agrarian University, Ukraine (UA).

Oksana GRYTSYNA, Associate Professor, Department of Finance, Banking and Insurance, Lviv National Agrarian University, Ukraine (UA)

Heorhiy CHEREVKO, Professor of the Department of Economics and International Economic Relations Zheshov University, Poland (Pl).

Olha SHOLUDKO, Associate Professor of the Department of Finance, Banking and Insurance at Lviv National Agrarian University, Ukraine (UA).

Ruslana SODOMA, Associate Professor of the Department of Finance, Banking and Insurance at Lviv National Agrarian University, Ukraine.

(C) The Authors. Published by Blue Eyes Intelligence Engineering and Sciences Publication (BEIESP). This is an open access article under the CC BY-NC-ND license (http://creativecommons.org/licenses/by-nc-nd/4.0/)

\section{INTRODUCTION}

Under the conditions of integration of Ukraine to the world economic community, an agrarian sector is one of the foreground and strategically important industries of the national economy. In 2018, agricultural sector constituted $13 \%$ of gross domestic product.

At the same time, the modern state of the field is characterized by the problems determined by the peculiarity of the agricultural production and caused by its seasonality, large dependence on natural and climate factors, instability of prices on agrarian products, insufficient investment attractiveness of the industry, complication of involving credit resources.

Steady development of the agrarian sector of the Ukrainian economy largely depends on the efficiency of the agrarian policy and appropriate state participation in its formation and realization.

Methods of direct influence are distinguished in the process of realization of the agrarian policy. They predefine such regulation when the subjects of the economy are imposed to make decisions which are based not on an independent economic choice, but on the state instructions. These are mainly changes in tax legislation, administrative limitations in the industry of quality control of food production, etc. Methods of direct influence can often be the most effective in achieving economic result, though they have crucial drawbacks related to the creation of obstacles in the market process.

Changes in taxation on the whole, and in taxation of agricultural enterprises in particular, refer to refilling of state budget of Ukraine. Tax Code of Ukraine and its constant improvement and amendment testifies this. A desire to create optimally balanced system of taxation still remains urgent, notwithstanding the existing insufficient financial support of the industry. In this publication we offer to pay attention to creation of such a system of taxation of agricultural enterprises where the principles of social equity and minimal tax burden would be followed.

\section{LITERATURE REVIEW}

Among modern European experts, the problem of special taxation and the improvement of its administration are researched by L. Barbone [Barbone, 2012], T. Grills [Grills, 2010], P. Dylewskiy [Dylewskiy, 2017], W. Hellerstein [Hellerstein, 2010], M. Keen[Keen, 2011], J. Vazguez-Caro [Vazguez-Caro, 2012], Šimović, H. [Šimović, 2016].

Published By:

Blue Eyes Intelligence Engineering

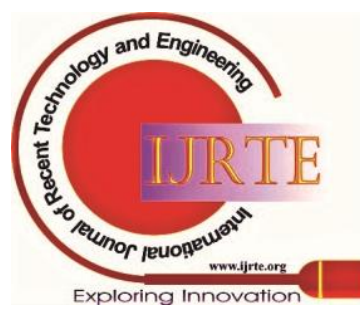




\section{Direct Taxation of Agricultural Enterprises}

Taxation of agricultural activity is a subject for researches of leading native scientists, such as Y. Lupenko [Lupenko, 2014], L. Tulush [Tulush, 2015], O. Soskin [Soskin, 2010], V. Synchak [Synchak, 2014] and others. Due to their efforts the system of special taxation of agrarian business was introduced which has become the basis for getting the industry out of crisis at the end of the past and beginning of this century. In particular, V. Synchak [Synchak, 2014] worked out the Conception of development of taxation system of agriculture in Ukraine. L. Tulush [Tulush, 2015] pays much attention to the problems of functioning of special taxation regulations.

Many scientists aim their researches at solving modern problems of levying taxes using special schemes, intended use of VAT, etc. L. Tulush points out, that present fiscal state policy as to agrarian sector of economy is not comprehensive and systematic, has a number of disadvantages that does not provide creation of favorable institutional environment and equal conditions for doing business in this field [Tulush, 2014a; 2014b].

Nevertheless, there is a range of unsolved problems which are significant impetus for the development of new mechanisms of optimal taxation of agricultural enterprises.

\section{RESEARCH METHODS}

The theoretical and methodological basis of the research is the basic provisions of modern economic theory, the work of leading domestic and foreign scientists on the issues of taxation of agricultural enterprises. The methodological basis of this research is the work of scientists in the field of direct taxation of agricultural enterprises. Using the systematic reproduction approach in the study allows us to show the process of interaction between the of direct taxation and the real economy as a set of functioning elements of the Ukrainian economic system.

In the research, we used general scientific and specific economic methods, as well as a basic research approach that allowed us to determine the economic nature and scope of direct taxation of agricultural enterprises.

In article all materials are worked out by means of a complex of methods of scientific research, in particular the direct description of the studied phenomenon, processing of statistical information by means of economic methods of a research, representation of the received results by means of a tabular form and a graphic method. In particular, calculation and analytical - to assess the tax burden on enterprises in the agricultural sector; comparative - to compare trends in tax regulation of the agricultural sector at different time intervals, logical generalization and extrapolation - to justify qualitatively new approaches and develop proposals for modernization of tax mechanisms for taxation of agricultural enterprises; graphical and tabular - to provide the calculated part of the study and a visual presentation of its results during the processing of statistical data.

The purpose of the research is to distinguish the peculiarities of direct taxation of Ukrainian agricultural enterprises and to suggest the ways for lowering the tax burden on agricultural enterprises of various organizational and legal forms.

\section{RESULT AND DISCUSSION}

The systems of taxation across the world have various classifications, based on different criteria: i.e. with respect to the dependence of tax rates on the object of taxation, progressive and flat taxation systems could be distinguished [Kosova, T., Slobodyanyuk, N., Polzikova, H., \& Šatanová, A., 2018]. As the agrarian industry was in the critical condition, the government undertook essential measures for a considerable simplification of agricultural enterprises taxation. Changes in tax legislation for the agrarian sector began when the Law of Ukraine "On the fixed agricultural tax" № 320 was adopted on 17 December, 1998, which introduced this payment as a tool of stimulation of agricultural production. The necessity of changes was stipulated by unprofitability or low profitability of agricultural production, as well as by the urgent necessity of the state support of this industry, insufficiency or absence of money turnover in it, by the necessity of simplification of the tax accounting, etc. According to this document, one tax has replaced twelve obligatory payments with different taxation bases.

The payers of the fixed agricultural tax (further - FAT) were agricultural enterprises, which revenue, received from selling of agricultural goods of their own production and goods of their processing for a previous financial (tax) year, exceeded $50 \%$ of the total sum of gross profit.

The object of taxation was a certain area of the agricultural lands passed to the agricultural producer in property or given for the usage, among others under the term of lease.

The rate of FAT, set in percent to the monetary estimation of agricultural lands, was calculated in accordance with the methodology, approved by the Cabinet of Ministry of Ukraine, in the following measures: for plough-land, hayfield and pastures - 0,5\% (for mountainous areas and Polissia territories - 0,3\%) and for the long-term planting - 0,3\% (for mountainous areas and Polissia territories $-0,1 \%$ )

The payment of tax (including a natural form) had to be made monthly by the $20^{\text {th }}$ number of the following month in amount of one third of the tax sum, defined for every quarter, from the annual tax sum, in such amount: in I and II quarters - by $10 \%$; in III quarter - $50 \%$; in IV quarter - $30 \%$. The function of this Law was foreseen to limit by 01.01.2004.

According to the first edition of Law № 320, payments to the social funds were included into the list of collections, which were replaced with FAT. However, this norm was already corrected on 03.02.1999 by Law № 414 - XIV "On making changes to the article 9of the Law of Ukraine On the fixed agricultural tax". The total sum of FAT was divided into several parts: $68 \%$ was deducted on the obligatory state pension insurance and $2 \%$ - on the obligatory social security. This order of payment of non-budget social contribution was relevant by 2005 .

In 2003, the possibility to pay tax in a natural form was abolished by the Law № 659 - IV of 03.04.2003 “On making changes to the Law of Ukraine "On the fixed agricultural tax".

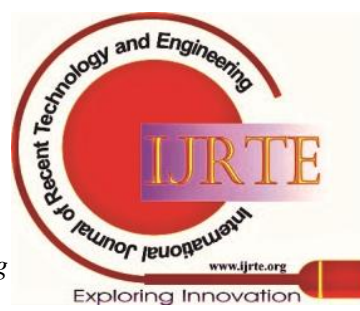


The objects of taxation were complemented by the lands of water fund, used by the mentioned businesses for breeding, growing and fishing-out of fish in internal reservoirs (lakes, ponds and storage pools). The tax rate was set at the level of $1,5 \%$ of monetary estimation of the unit of plough-land area in regions and AR Crimea [Law of Ukraine 2003].

Since 1 January, 2004, the Law № 974 - IV of 19.06.2003 "On making changes to some Laws of Ukraine as to the activity regulation in the agrarian sector of the economy" set a number of important items:

collection to the Fund for the implementation of measures as to the liquidation of the consequences of the Chornobyl accident and social protection of population as well as collection to the State innovative fund were excluded from the list of taxes and collections that FAT substituted because of their abolishment;

in order to get status of a FAT payer, the sum, received by an agricultural enterprise from selling of agricultural goods of its own production and goods of their processing for a previous financial (tax) year, had to exceed $75 \%$ (not 50\%) in the total sum of the gross profit [Law of Ukraine 2003]. This condition is still in effect.

Action of FAT was continued to 1 January, 2009.

The Law № 1878 - IV of 24.06.2004 "On making changes to some Laws of Ukraine as to the taxation of agricultural enterprises and support of social standards of their workers" came into force on 1 January, 2005. Due to this, steps were made to eliminate payments to non-budget social funds from FAT and gradually transfer the order of payment of these collections by agricultural enterprises on the general basis.

Gradual elimination of payments to non-budget funds for special purposes from FAT also became the factor of the increase of fiscal pressure, maybe even more significant than the change of the basis of taxation and rates.

At the end of 2006, agricultural producers were given an allowance as to a tax from the owners of transport vehicles and other self-powered machines and mechanisms, that actually removed this tax from FAT structure. Action of FAT was again continued to 1 January, 2011.

Adoption of the Tax Code is considered to be the next stage in the evolution of FAT, though philosophy of this tax did not change, however, a number of its elements experienced changes. Since the beginning of 2011, payers of FAT did not pay tax on enterprise profit, on land (except tax for land lots not used for agricultural production), tax for special use of water and for carrying out of certain types of entrepreneurial activity (in part of conducting trade activity). Other taxes and collections were paid by the tax payer in the order and amount set by the Code, and the single payment on the obligatory state social insurance was paid in the order determined by the Law "On collection and accounting of single payment on the obligatory state social insurance".

Since 01.01.2015 according to the changes in the Tax Code a uniform tax of IV group appeared, which was altered from the FAT, but the rates were tripled compared to the FAT and taxation base also increased several times. Therefore, for agricultural enterprises that possessed large amounts of lands but with low revenue from their usage the status of the uniform tax payer was not feasible. Since 01.01.2016 uniform tax rates increased by 1.8 times, correspondingly increasing the tax burden on agrarians. Due to the indexation of monetary valuation of land, rent for land plots also rises, increasing the fiscal pressure.

Tabl - I.. Dynamics of united tax rates for agricultural producers *

\begin{tabular}{|c|c|c|c|}
\hline \multirow[t]{2}{*}{$\begin{array}{l}\text { Types of land } \\
\text { parcels }\end{array}$} & \multicolumn{3}{|c|}{$\begin{array}{l}\text { Rate of the united tax, from the regulatory monetary } \\
\text { estimation \% }\end{array}$} \\
\hline & general & $\begin{array}{l}\text { in mountainous } \\
\text { areas and } \\
\text { polissia territories }\end{array}$ & in protected areas \\
\hline $\begin{array}{c}\text { Plough-lands, } \\
\text { hay meadows, } \\
\text { pastures }\end{array}$ & $\begin{array}{c}2017-2020-0.95 \\
2016-0.81 \\
2015-0.45 \\
1999 * *-0.15\end{array}$ & $\begin{array}{c}2017-2020-0.57 \\
2016-0.49 \\
2015-0.27 \\
1999 * *-0.09\end{array}$ & $\begin{array}{c}2017-2020-6.33 \\
2016-5.4 \\
2015-3.0\end{array}$ \\
\hline $\begin{array}{l}\text { Long-term } \\
\text { planting }\end{array}$ & $\begin{array}{c}2017-2020-0.57 \\
2016-0.49 \\
2015-0.27 \\
1999 * *-0.09\end{array}$ & $\begin{array}{c}2017-2020-0.19 \\
2016-0.16 \\
2015-0.09 \\
1999 * *-0.03\end{array}$ & - \\
\hline $\begin{array}{l}\text { Water fund } \\
\text { lands }\end{array}$ & $\begin{array}{c}2017-2020-2.43 \\
2015-1.35 \\
1999 * *-0.45\end{array}$ & - & - \\
\hline
\end{tabular}

Source: Compiled by the authors based on Ministry of Finance of Ukraine, 2019

Thus, the growth of the absolute rate of the united tax from 1 hectare of agricultural lands caused the increase of the tax burden, that grew dynamically from $1,6 \%$ in 2014 to $15,48 \%$ in 2017.

The experience of uniform tax (primarily FAT) existence shows that it has stopped performing its stimulating function for small and medium-sized businesses in villages. Moreover, along with emergence of agroholdings which concentrate and use large squares of agricultural land, it has transformed into the mechanism of tax optimization for the latter. Unfortunately, such concentration of land by agroholdings will lead to displacement of small producers from countryside.

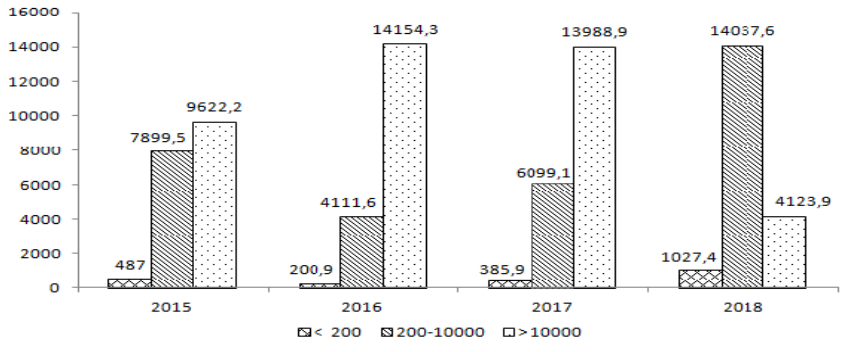

Fig. 1: Area of land in processing by enterprises- payers of 4 group of uniform tax, thousand hectares.

Source: Compiled by the authors based on Ministry of Finance of Ukraine, 2019

In our opinion, the use of special taxation regime for any organizational and legal forms and types of agricultural activity leads to uneven tax burden on different groups of agriculture producers and to forming irrational agriculture production structure. The present tax practice causes considerable budget losses which are not compensated with additional increase of investment expenses and of the level of employment.

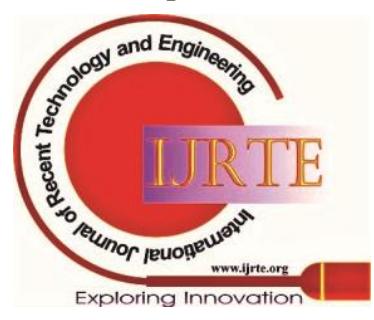




\section{Direct Taxation of Agricultural Enterprises}

Hereby, economic motivation of farming subjects in agrarian sector is violated, particularly in the part of low-marginal, but socially-oriented types of agricultural activity. Aiming at levelling out taxation conditions for different groups of agriculture producers (forms of farming), preserving investment activity in the sphere and increasing the level of employment in the countryside realization of the following measures in the sphere of direct taxation is expedient:- improving the mechanism of paying uniform tax limiting spheres of its usage only by subject for which agricultural land is the key condition to conduct the activity and plant growing is the main (prevailing) kind of activity

- making agricultural producers which are specialized in animal products and vegetables free from taxation if the production is directed to the development (particularly to capital investments in material and technical base development) encouraging agricultural enterprises to take part in the programme of rural territories development, according to whose land they use.

- introducing control of transfer price formation by some producers, first of all economic structures which don't take an active part in social-economic development of rural community on the place of land usage.

-stimulating rational land usage and preventing profiteering agricultural land at the cost of improving the mechanism of land payment.

Today, tax policy of the most countries of the world, unlike Ukrainian, aims at simplification of administration and reduction of tax rates. Countries of the world compete at the global market, but Ukraine still continues to play using old principles causing harm first of all to itself, i.e. to the society.

Summarizing the results of the research, we consider that the mechanism of direct taxation is one of the significant levers of the state financial control of the agrarian sector development of Ukraine.

In order to solve the problems of taxation in the agrarian sphere of the economy of Ukraine, it is necessary to organize three groups of agricultural producers: use);

- small family farm units (up to 200 hectares of land in

- farms and medium-sized agricultural enterprises, that fit the rural settlement i.e. their activity is provided within the territory of a settlement;

- large farm agricultural companies that comprise from a few settlements up to 20-22 regions.

We suggest implementing separate tax policies for every group. For small producers, a simple uniform land tax should be inscribed in legislation. For farms and medium-sized agricultural companies, a fixed agricultural tax based on normative monetary land valuation should be returned. For the third category (agroholdings), it is feasible to use the general taxation system.
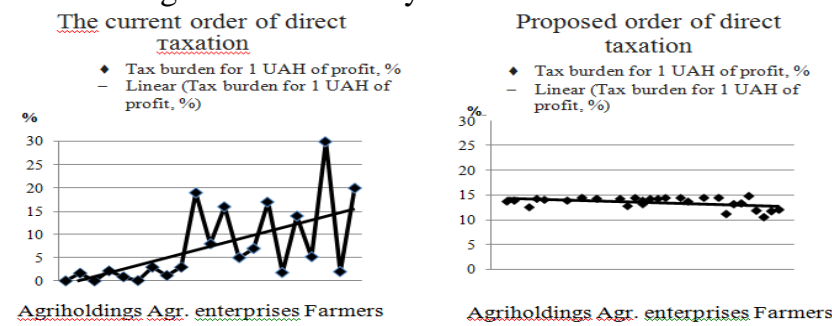

Fig.2: Distribution of tax load among agricultural producers
Source: Compiled by the authors based on Ministry of Finance of Ukraine, 2019

Implementation of the offered suggestions will reduce the variety of indexes of the tax burden on the enterprises of different legal forms and will allow to balance the competitive conditions for different forms of business and rational use of the current tax potential of the subjects of agribusiness.

The introduction of innovative forms of remote servicing expands the profile of traditional risks and creates new sources of their occurrence [Yakubiv, V., Sodoma, R., Hrytsyna, O., 2019].

\section{CONCLUSIONS}

Thus, the evolution of FAT, and further the unified tax for the fourth group, proves that this tax was gradually losing its regulation function, but changes in taxation strengthened its fiscal value. Considerable increase of the tax burden on agribusiness is the result of not only the desire of the government to make the level of the budget income higher, but also the fact that rates and taxation basis were neither looked over nor brought in balance with the existing economic conditions for a long time.

Considering the practice of current system of taxing agricultural producers we emphasize main tasks of its reforming:

- levelling out taxation conditions for different categories of producers and different kinds of agricultural activity

- minimization of negative influence on the economic decisions of farming subjects and their investment activities

- formation of sufficient and reliable source of financial resources for funding measures concerning social development of the corresponding territories.

- making impossible to spread optimization al tax schemes which cause distortion of economic mechanism activity in the sphere and financial abuse which is especially intolerable under the condition of the deficit of the state financial resources.

Thus, the further development of tax policy in the field of agro-industrial production should ensure optimal implementation of fiscal (ensuring the appropriate resource base of local government budgets in rural areas) and regulatory (equalization of economic conditions for different categories of producers) tasks facing the tax system in the agricultural sector. The introduction of this approach to the formation of tax mechanisms in the field of agriculture will make it possible to realize the tax potential of agricultural producers and ensure the regulatory impact of taxation on economic processes.

\section{REFERENCES}

1. Barbone, L., Bird, R. M., \& Vázguez-Caro, J. (2012). The Costs of VAT: A Review of the literature. [The Costs of VAT: A Review of the literature] Center for Economic and Social Research, Case Networ Reports No. 106/2012. doi: https://doi.org/10.2139/ssrn.2024880

2. Hellerstein, W., \& Grills, T. H. (2010, April 26). The VAT in the European Union. Tax Analysts, 461-471. Retrieved from https://taxprof.typepad.com/files/127tn0461.pdf

3. Keen, M. (2012). Taxation and Development - Again. International Monetary Fund, Fiscal Affairs Department. IMF Working Paper12/220. Retrieved from https://www.imf.org/

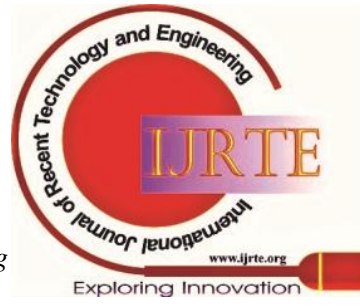


external/pubs/ft/wp/2012/wp12220.pdf

4. Killington, K., \& Dylewski, P. (2017, June 15). VAT deduction and noneconomic activities: art or science? Tax Journal, 14-15. Retrieved from https://home.kpmg.com/content/ dam/kpmg/uk/pdf/2017/06/vat-deduction-and-non-economic-activitie s.pdf

5. Kosova, T., Slobodyanyuk, N., Polzikova, H., \& Šatanová, A. (2018) Tax gap management: theory and practice. Economic Annals-XXI, 174(11-12), 22-28 Retrieved from https://doi.org/10.21003/ea.V174-04

6. Lupenko Yu.O (2014) Special taxation modes in the Ukrainian agricultural sector. (The CAP and competitiveness of the Polish and European food sectors) 6:106-117Retrieved from http://soskin.info/ea/2010/3-4/201022zmist.html [In Ukrainian]

7. Ministry of Finance of Ukraine (2019). Richnij zvit 2019. Available at: $\quad$ https://mof.gov.ua/uk/set-of-summarizing-tax-consultations Retrieved from https://mof.gov.ua/uk [In Ukrainian]

8. Simović, H., \& Deskar-Škrbić, M. (2016). Value Added Tax Efficiency in Croatia. EFZG Working paper series, 16-02. Zagreb: Faculty of Economics. Retrieved from https://hrcak.srce.hr/file/223529 [In Croatian]

9. Soskin, O. I. (2010). Transformations of the tax system in the context of the modern economic model of Ukraine. Economic Annals-XXI, 3-4, 7-14. Retrieved from http://soskin.info/ea/2010/3-4/201022zmist.html [In Ukrainian]

10. Sinchak V. P. (2014) Taxation of agricultural enterprises - owners of vehicles. Economics of AIC 15-26. Retrieved from http://bigpo.ru/potr/ agricultural enterprises /part-4.html

11. The Law of Ukraine On fixed agricultural tax. (of 17 December 1998 № 320-XIV) http://zakon0.rada.gov.ua/laws/show/320-14. [In Ukrainian]

12. The Law of Ukraine On making changes to the article 9 of the Law of Ukraine "On fixed agricultural tax”. (of 03.02.99 № 414-XIV) http://zakon0.rada.gov.ua/laws/show/414-14. [In Ukrainian]

13. The Law of Ukraine On making changes to the Law of Ukraine "On fixed agricultural tax”. (№ 659-IV of 03.04.2003) http://zakon0.rada.gov.ua/laws/show/659-15. [In Ukrainian]

14. The Law of Ukraine On making changes to some laws of Ukraine as to activity regulation in the agrarian sector of the economy. The Law of Ukraine (№ 974-IV of 19.06.2003). http://zakon0.rada.gov.ua/laws/show/974-15. [In Ukrainian]

15. The Law of Ukraine On making changes to some Laws of Ukraine as to the taxation of agricultural enterprises and support of social standards of their workers. (№ 1878-IV of 24.06.2004). http://zakon0.rada.gov.ua/laws/show/1878-15. [In Ukrainian]

16. The Law of Ukraine On making changes to the Internal Revenue Code of Ukraine and some legislative acts of Ukraine as to tax reform. (№71-19 of 28.12.2014). http://zakon0.rada.gov.ua/laws/show/71-19. [In Ukrainian]

17. The Law of Ukraine On making changes to the Internal Revenue Code of Ukraine and some legislative acts of Ukraine as to provision of balance of budgetary receipts in 2016. (№ 909-VIII of 24.12.2015) http://zakon0.rada.gov.ua/laws/show/909-19/page [In Ukrainian]

18. Tulush LD (2014) Enforcement of regulatory functions of the direct taxation in agribusiness Scientific notes of " $K R O K$ " University. (J Economics) 35, 85-93 Retrieved from http://nbuv.gov.ua/UJRN/Vzuk_2014_35_14. [In Ukrainian]

19. Tulush L. D (2015) Tax policy efficiency in agriculture of Ukraine. Economic Annals-XXI (5-6), 49-52 Retrieved from http://soskin.info/en/ea/2015/5-6/contents_12.html

20. Yakubiv, V.; Sodoma, R.; Hrytsyna, O.; Pavlikha, N.; Shmatkovska, T.; Tsymbaliuk, I.; Marcus, O.; Brodska, I. (2019). Development of electronic banking: a case study of Ukraine. [Development of electronic banking: a case study of Ukraine]. Entrepreneurship and Sustainability Issues, 7(1): 219-232. Retrieved from http://doi.org/10.9770/jesi.2019.7.1(17) [In English]

\section{AUTHORS PROFILE}

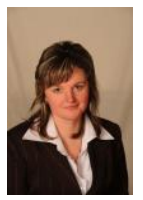

Lyubov SYNYAVSKA - Candidate of Economic Sciences and Associate Professor of the Department of Finance, Banking and Insurance, Lviv National Agrarian University, Ukraine (UA). Experience of practical work in production is more than 6 years. Scientific and pedagogical experience over 20 years. Deputy Head of the Department of Finance, Banking and Insurance for Research. Investigates the issue of taxation in agriculture. She is the author of more than 60 scientific and educational works, co-author of 6 monographs, 2 foreign publications. She defended her dissertation on "Taxation of agricultural producers and ways to improve it." Underwent advanced training in Poland. Research interests: direct taxation, tax relations, organizational and methodological principles of corporate taxation, fiscal policy, budget sphere.

ORCID ID: https://orcid.org/0000-0002-2723-9551

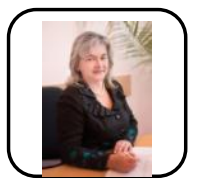

Oksana GRYTSYNA is the Ph.D. in Economics and Associate Professor of the Department of Finance, Banking and Insurance at Lviv National Agrarian University, Ukraine (UA). Head of the Department of Finance, Banking and Insurance from 2017 to the present. Scientific and pedagogical experience over 20 years. Author of 80 scientific papers, including 6 monographs, 4 foreign publications, 1 textbook, 1 articles in international collections with the citation index SCOPUS and Web of Science. Underwent advanced training in Poland. Honorary member of the Academic Council of the UniversityResearch interests: organizational and methodological principles of taxation of the enterprises, internet banking.

ORCID ID: https://orcid.org/0000-0002-1304-0250

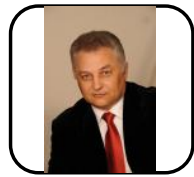

Heorhiy CHEREVKO is the DrSc in Economics and Professor of the Department of Economics and International Economic Relations Zheshov University, Poland (Pl). The is author of 600 scientific works, of which 180 are scientific and 100 educational and methodical in nature, including 16 monographs, 10 textbooks, 170 professional articles, 35 in the international collections with the citation indexes Google Scholar, Copernicus, 90 abstracts at conferences, 1 copyright certificate and others. He passed internships in the USA, Germany, Poland. Member of the International Association of Economists. Editor-in-Chief of a professional scientific publication that is part of the international scientific base. Research interests: management in the field of innovative agriculture.

ORCID ID: https://orcid.org/0000-0003-4339-0152

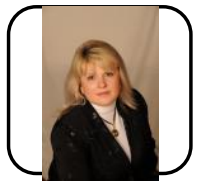

Olha SHOLUDKO is the Ph.D. in Economics and Associate Professor of the Department of Finance, Banking and Insurance at Lviv National Agrarian University, Ukraine (UA). Scientific and pedagogical experience over 20 years. Deputy Head of the Department of Finance, Banking and Insurance for Academic Affairs. . Author of 60 scientific papers, including 4 monographs. She is the author of 45 professional articles, in the international collections with the citation indexes Google Scholar, Copernicus, 102 abstracts at conferences and others. Underwent advanced training in Poland. Research interests: lending to agrarian enterprises, lending to agrarian enterprises; internet banking; bank lending operations.

ORCID ID: https://orcid.org/0000-0003-2264-5638

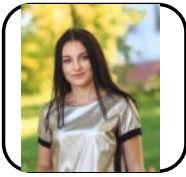

Ruslana SODOMA is the Ph.D. in Economics and Associate Professor of the Department of Finance, Banking and Insurance at Lviv National Agrarian University, Ukraine. Her work has attracted the Diplomas of the Lviv National Agrarian University. In 2014, she defended her dissertation on the topic: "Credit relations of agricultural enterprises with banks". Underwent advanced training in Poland. She is the author of more than 55 scientific works, including 4 articles in the international collections with the citation index SCOPUS and 3 in the international collection with the citation index Web of Science. Research interests: lending to agrarian enterprises; payment systems; internet banking; bank lending operations.

Scopus Author ID: 56669972700

ORCID ID: https://orcid.org/0000-0002-5020-6440

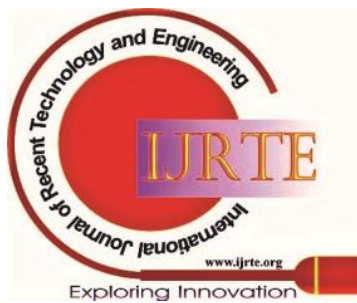

